\title{
LATOURIN DISIPLIINI
}

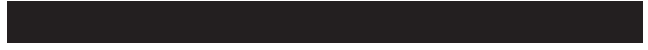

Bruno Latour: Cogitamus. Six lettres sur les humanités scientifiques. La Découverte, Paris 2010, $249 \mathrm{~s}$.

Pierre Bourdieun kerrotaan joskus todenneen tutkimuksestaan, että se on "kenttätyötä filosofiassa". Luonnehdinnan voi ymmärtää parillakin tapaa. Yksinkertaisimmillaan se tarkoittaa, että ollaan kiinnostuneita siitä, mitä filosofit käytännössä tekevät, minkälaisissa yhteyksissä ja minkäkinlaisin panoksin. Hahmotetaan, mikä on filosofian "kenttä". Tällaista tutkimusta Bourdieu itse jonkin verran harrasti. Olennaisempaa ajatuksessa kuitenkin lienee filosofiksi peruskoulutetulle Bourdieulle jokin muu: yhteiskunnallisia käytäntöjä tutkitaan filosofisten käsitteiden valossa, niitä vasten ja ehkä niitä muuntaenkin. Kysytään filosofisia kysymyksiä suhteessa johonkin itsessään ei-filosofiseen aineistoon, joka kerätään "kenttätyöllä" antropologien tapaan. Tällaista etnografista kenttätyötä Algeriassa tehdenhän Bourdieu oli aloittanut varsinaisen tutkijanuransa. Jos "kenttätyö filosofiassa" tulkitaan jälkimmäisellä tavalla, on helppo ajatella, että tämä luonnehdinta osuu myös Bruno Latourin tuotantoon. Bourdieun lailla hänellä on filosofin peruskoulutus ja kokemusta antropologisesta tutkimuksesta Afrikassa. Latourin uusinta teosta nimeltä Cogitamus voikin lähestyä oppikirjana siitä, miten kenttätyötä hänen mielestään pitää tehdä.
TIETEEN TUTKIMUS, SOSIOLOGIA, ANTROPOLOGIA, FILOSOFIA - JA KENTTÄTYÖ

Bourdieusta tuli lopulta kuuluisa sosiologina. Filosofia ja antropologia muistetaan mainita hänen työnsä suhteen kuriositeetteina, lisää akateemista uskottavuutta tuovina ja monipuolista oppineisuutta korostavina taustoina - mutta kuitenkin vain taustoina.

Latourista ei sen sijaan oikein tiedä, mikä hänestä on tullut. Selviö on, että Latourilla on merkitystä ensinnäkin tieteen ja teknologian tutkimuksen kehittäjänä ja tunnetuksi tekijänä, vaikka hän tuon alan kentällä herättääkin monenlaisia mielipiteitä. Toiseksi myös sosiologiassa hänestä on viime vuosina tullut tähti, vaikka keskeinen juonne hänen tuotannossaan on etäisyyden ottaminen tämän oppialan perinteisiin nähden niin tutkimuskohteiden, käsitteiden kuin kirjoitustavankin suhteen. Antropologia on kolmas oppiala, johon Latourin voi yhdistää. Hän on tuonut moneen kertaan esiin, että antropologinen kenttätyö on hänelle tutkimuksen tekemisen ihanne. Erilaisten disipliinien joukossa suhde filosofiaan on kuitenkin ehkä kaikkein rikkain ja hämmentävin Latourin työn viitepiste. Ei olekaan yllättävää, että paras johdatus hänen tuotantoonsa on filosofin laatima: Graham Harmanin kirja Prince of Networks. Bruno Latour and Metaphysics (2009; ks. myös Latour ym 2011). Harman erittelee oivaltavasti, kriittisesti ja hauskasti Latourin tuotannon arvoa nimenomaan filosofian kannalta. Hän painottaa Latourin merkitystä metafyysik- 
kona, spekulatiivisen filosofian kehittäjänä, ja jopa väittää Latourin metafysiikan olevan "aikamme aliarvostetuin filosofia" (Harman 2009, 6).

Harmanin kirjassa on kuitenkin merkittävä puute: se ohittaa lähes kokonaan Latourin erityiset kenttätyöt. Aivan kuin Latourin ajatteluun ei olisi vaikuttanut pitkä perehtyminen laboratorioiden ja tutkimusryhmien toimintaan, insinöörien suunnittelukäytäntöihin tai vaikkapa juristien arkiseen työhön. Harman painottaa Latourin panosta metafysiikkaan tavalla, joka varmasti on kaiken tulevan Latour-keskustelun mittapuu. Mutta hän ei tee täyttä oikeutta Latourin tutkimuksestaan käyttämien luonnehdintojen "empiirinen filosofia" tai "kokeellinen metafysiikka" rikkaudelle. Harmanin luennassa näiden määreiden ensimmäiset osat supistuvat pois. Tähän liittyy, että yksi Latourin keskeisistä käsitteellisistä välineistä, "koetus", ohitetaan Prince of Networks -kirjassa nopeasti.

Kun lukee Cogitamusta, ei tunnu kuitenkaan yllättävältä, että oivaltavin Latour-kommentaari ohittaa kenttätyön merkityksen. Nimittäin Cogitamus on jo kuudes - todellakin, kuudes - Latourin laajahko "johdatus" hänen omaan tapaansa ajatella ja tehdä tutkimusta. Sitä ovat edeltäneet Science in Action (1987), Pandora's Hope (1999) ja Reassembling the Social (2005). Myös Pasteur-tutkimuksen toisena puolena julkaistu Irréductions (1984) sekä hiljan suomennettu Emme ole koskaan olleet moderneja (2006 [1991]) ovat selkeän ohjelmallisia. Harman keskittyy nimenomaan näihin teoksiin ja sivuuttaa Latourin monien kenttätöiden merkityksen tutkimansa metafysiikan kannalta. Se, että niin Harman kuin Latour itsekin keskittyvät ohjelmallisiin teksteihin, tuntuu kuitenkin olevan vastoin Latourin ohjelman sisältöä: metafysiikka voi olla "kokeellista" vain, jos se kohtaa asioita ja ajatuksia, joita ei ole voitu ennakoida ja jotka tulevat esille laboratorioissa tai - yhteiskuntatieteen yhteydessä - kenttätyön kautta. Se vaatii ei-filosofista ainesta tullakseen koetelluksi (Lehtonen 2000).
Mutta miksi Latour itse kirjoittaa yhä uudestaan ohjelmia, miksi hän ei keskity ajattelunsa koettelemiseen kenttätöissä? Ensinnäkin voitaisiin ajatella, että ohjelma muuttuu hiukan kirjasta toiseen. Cogitamuksen kohdalla tämä ei kylläkään pidä paikkansa: kirja ei esittele olennaisia käsitteellisiä keksintöjä tai ajattelutavan muokkausta aiempaan nähden. ${ }^{1}$ Toinen mahdollinen vastaus olisi yhtä helppo mutta myös yhtä epätyydyttävä: Latourin tekstejä sovelletaan nykyään niin paljon erilaiseen tieteen ja teknologian tutkimukseen ja yleisemminkin yhteiskuntatieteeseen, että hänen itsensä ei enää tarvitse vaivautua kenttätyöhön. Mielestäni näitä kahta ajatusta tärkeämpi on kolmas: ohjelmallisilla kirjoilla voidaan yhä uudestaan vankistaa sitä disipliiniä, jota Latour ajaa tutkimukseen. Hän antaa sääntöjä ja neuvoja sen suhteen, miten konkreettisesti tutkimuksissa edetä. Samalla syntyy ihan oma oppiala. Disipliinillä on myös merkitystä kurina, kun kerrotaan, mitä saa ja kannattaa tehdä,ja erityisesti kun painotetaan, miten $e i$ pidä ajatella tai miten $e i$ pidä käsitteellistää maailmaa. Disipliini on opettamisessa keskeistä, ja juuri opettamisen tarpeista on syntynyt myös Cogitamus.

KIRJE(YLI)OPISTO

Latourin tuotannolle on ominaista, että hän käyttää hyväksi kertomisen konventioita, esimerkiksi dialogia, paljon laajemmin kuin akateemisessa kirjallisuudessa on tavanomaista. Niin myös Cogitamuksessa, joka koostuu kuudesta saksalaiselle opiskelijalle kirjoitetusta kirjeestä. Ne tiivistävät Latourin pitämän luentosarjan ydinasiat nuorelle naiselle, joka ei kuitenkaan koskaan vaivaudu itse opetustapahtumiin, koska saa opettajaltaan kaiken valmiina sähköpostien muodossa... Taustana on Latourin työpaikassaan yhteiskuntatieteellisessä korkeakoulussa Science Po:ssa oikeasti pitämä luentosarja. Kysymys on jonkinlaisesta tutkimusharjoituskurssista, johdatuksesta 
latourilaiseen kenttätyöhön, jossa sovelletaan hänen esittelemiään käsitteitä. Tarkastellaan tieteiden ja teknologioiden suhdetta historiaan, kulttuuriin, kirjallisuuteen, talouteen ja politiikkaan. Tällä kertaa Latourin oma disipliini saa nimen bumanités scientifiques, "tieteelliset inhimillisyydet"; tämä on vaikea kääntää sujuvasti suomeksi, toki nimi tuntuu hieman kömpelöltä ranskaksikin. Selvästi kysymys on laajemmasta asiasta kuin "vain" tieteestä ja teknologiasta.

Ensimmäisessä kirjeessä tarkastellaan esimerkkejä siitä, miten tiede tai teknologia eivät ole riippumattomia yhteiskunnasta ja miksi tämä riippuvuus on monensuuntaista. Toisessa käsitellään koetuksia ja tavoitteiden muutoksia, "kiertoteitä", joita teknologiat käyttäjilleen tuottavat ja joiden kautta teknologiat itse muuttuvat käytettäviksi. Kolmas keskustelee kielestä, todistuksista ja tieteellisen varmuuden tuottamisesta sekä siitä, miten itsessään ei-kielelliset asiat saadaan kirjautumaan tieteen kieleksi. Ajattelu osoittautuu perustaltaan kollektiiviseksi asiaksi, mistä myös kirjan nimi: cogitamus on latinan ajatella-verbin monikon ensimmäisen persoonan muoto. Neljäs kirje avaa instrumenttien merkitystä siinä, miten paikallinen tieteellinen tieto voidaan yleistää. Jotta tieto ei jää laboratorioon, sen on kyettävä liikkumaan asioiden erilaisten kokoluokkien välillä. Viimeisissä kirjeissä tarkastellaan tieteen käytännön suhdetta tieteen käsitteeseen, julkisuuteen sekä maailman järjestämiseen eli kosmopolitiikkaan.

Vaikka Cogitamus ei kerro kenttätyöstä - ellei sen kehyskertomusta ota kenttätyönä opettamisesta - se on täynnä esimerkkejä, joiden kautta Latour valottaa ajatteluaan. Kurssilla opiskelijat laativat opintopäiväkirjan, johon kerätään itse haalittua dokumentaatiota teemaan sopivista uutisista ja ajankohtaisista tapahtumista. Tällaisia esimerkkejä Latour avaa joka kirjeessä muutamia, ja ne ovatkin havainnollisia. Kirjan ehkä kiinnostavin tällainen jakso käsittelee Ötziä.
ÖTZI JA IHMISELÄMÄN

KIERTOTEISTYMINEN

Ötziksi on nimetty 1991 Alpeilta Tirolista löytynyt, viitisen tuhatta vuotta sitten kuollut "lumimies". Jäätymisen tähden hänen ruumiinsa on säilynyt erinomaisesti, samaten kaikki hänen vaatteensa ja tarvikkeensa: aseet, pieni tulentekovälineistö, läkintäpussi sekä ruoka. Latourille Ötzi on hyvä viitepiste, kun puhutaan elämänmuotojen muutoksesta. Ötzin välineet kertovat siitä, miten inhmillinen vuorovaikutus on perustavasti erilaista kuin esimerkiksi paviaanien tai muiden kädellisten apinoiden. Nämä jälkimmäiset joutuvat ylläpitämään yhteisyyttään herkeämättä äänillä ja kosketuksilla. Ellei näin tehdä, yhteiselämää uhkaa sekaannus. Ihmisten vuorovaikutukset ovat sen sijaan kirjautuneet moninaisiin välineisiin, jotka myös ratkaisevasti vaikuttavat siihen, miten ihmiset toisiinsa suhtautuvat. Paviaanit ovat välittömästi kiinni niin toisissaan kuin fyysisessä maailmassa ympärillään, ilman toimintaa etäisyyden päästä. Ötziä erottaa kädellisistä apinoista hänen käyttämiensä välineiden hienostuneisuus. Meistä nykyihmisistä puolestaan häntä erottaa se, että hän on voinut joko itse valmistaa kaikki tarvitsemansa asiat tai saada ne lähiympäristöstään.

Kädellisiltä apinoilta peritty sosiaalisuus pysyy inhimillisen vuorovaikutuksen perusaineksena. Mikä sitten tarkkaan ottaen on toisin? Ensinnäkin keksinnöt muuttavat sitä kokonaisuutta, jossa ihminen elää. Latour esittää, että historian aikana ilmaantuneet kyvyt säilyvät, kasaantuvat ja ryhmittyvät uudelleen. Mutta mikään yksittäinen keksintö ei ole täysin tuhonnut edeltäjiään. Niinpä Latourin mukaan ihmiskunnan historiassa on todella nähtävissä "tendenssi”, kokonaisuuden liikettä erityiseen suuntaan.

Toiseksi välineiden luomat mutkat ja kiertotiet pitenevät. Jokainen uusi askel tuo lisää eriytyneitä tietojen, taitojen ja tekniikoiden yhdistelmiä, jotka ovat riippuvaisia toisistaan. 
On vaikea kuvitella länsimainen nykyihminen tilanteessa, jossa hän joutuisi etsimään kaiken ravintonsa lähiympäristöstään tai jossa hänen elämänympäristönsä ja -kulkunsa kannalta merkityksellisiä toisia ihmisiä olisivat vain ne, joihin hänellä voi olla näkö- tai puheyhteys. Ötzin jousen kaikki osat ovat peräisin lähialueelta. Jos hän ei itse ole niitä valmistanut, ne ovat ehkä muutaman ihmisen hänelle välittämiä. Nyky-yliopiston tutkijan aseen, tietokoneen, lukemattomat osat sen sijaan tulevat moninaisten toimijoiden vaikutuksesta eri puolilta maailmaa. On mahdoton täsmällisesti laskea, kuinka monen ihmisen työpanos on tarvittu, että tutkija voi saada sen käyttöönsä.

Kolmanneksi Latourin mukaan monta eri osasta mukaan ottava inhimillinen toiminta ulottuu yhä pidemmälle niiden olioiden luontoon, jotka se ottaa mukaansa. Toki Ötzillä on rikas ymmärrys niiden erilaisten kasvien, eläinten ja maalajien ominaisuuksista, joita hän käyttää hyväksi. Hänen toimeentulonsa ei kuitenkaan riipu siitä, että hänen lajitoverinsa kykenevät pumppaamaan maan uumenista öljyä tai louhimaan harvinaisia mineraaleja. Nykyelämänmuotoon ei liity ainoastaan jyvälajien erotteleminen toisistaan, vaan yksittäisten jyvien genomin tunteminen ja muokkaus. Olemisen rakennusaineksiin kaivaudutaan kollektiivisesti yhä syvemmälle: molekyyleihin biologiassa, atomeihin kemiassa ja hiukkasiin fysiikassa. "Tämä on tärkeä kohta: vastoin vallalla olevaa ajatusta, jonka mukaan mitä enemmän tiede ja tekniikka ovat 'edistyneet', sitä enemmän 'menettäisimme välittömän kosketuksen asioihin', meidän suhteemme asioihin on selvästi intiimimpi kuin Ötzin" (s. 63).

Meidän aikakauttamme - kyllä, Latour puhuu epookista - erottaa Latourin mukaan aiemmista aivan erityisesti laboratorioiden väliintulot: tieteen käytännöt monitahoistavat teknisiä välityksiä ja kiihdyttävät niitä. Tähän liittyen Latourin nostaa esiin vielä yhden aikaamme leimaavan asian. Tekniikka ja tiede kietoutuvat lähtemättömästi julkisiin kiistoihin ja poliittiseen pätöksentekoon. "Huomaatte mihin yritän kuljettaa oppilaitani: mitä pidemmälle aika kuluu, sitä vähemmmän on mabdollista erotella toisistaan inhimillinen toiminta, tekniikan käyttö, kulku tieteen kautta ja politiikan valloitusretki” (s. 65). Tästä on kysymys uudessa aikakaudessa, jossa ihminen todella vaikuttaa maailmaan ja jota Latour muutamia geologeja seuraten nimeää antroposeeni-aikakaudeksi. Ehkä tämä onkin Cogitamus-kirjan selkein uutuus: puhe historian vaiheista on tuore teema Latourin teksteissä, varsinkin näin selkeästi artikuloituna.

\section{LOPUKSI}

Latourin teosten lumo on tullut niiden $\mathrm{ky}^{-}$ vystä olla sekä aktiivisesti suhteessa moneen disipliiniin että kuitenkin niiden ulkopuolella. Parhaimmillaan hän on ollut, kun hän on antanut filosofisen ajattelunsa kohdata jonkin erityisen tutkimuskentän elementit. Cogitamus-kirja ei tässä suhteessa kuulu tärkeimpiin Latourin teoksiin. Se ei tuo esille mitään tuoretta kenttää, joka panisi Latourin kirjoittajana koetukselle ja pakottaisi hänet selvästi aiemmasta poikkeavaan ajatteluun. Silti kirja tarjoaa monta havainnollista esimerkkiä ja antaa hyvän kuvan hänen tavastaan lähestyä kysymyksiä. Se vankistaa latourilaisen tutkimuksen omaa disipliiniä. Niinpä jos joku haluaa ryhtyä harjoittamaan kenttätyötä filosofiassa, Cogitamus antaa pätevän pakin käsitteitä ja lähestymistapoja, joita koetella itse valitsemallaan kentällä.

— TURO-KIMMO LEHTONEN 
1. Ohjelman muuttuminen saattaa sen sijaan hyvinkin pitää paikkansa myöhemmin tänä vuonna ilmestyväksi luvatun teoksen Enquête sur les modes d'existence. Une anthropologie des Modernes kohdalla. Latour sanoo esittävänsä siinä laajasti vuosikymmeniä kehittelemänsä filosofisen ohjelmansa. Tätä käsikirjoitusta on lähipiiri kommentoinut jo vuonna 2007 pidetyssä Latourin 60vuotiskollokviossa; ks. myös Latour 2010.

\section{KIRJALLISUUS}

Harman, Graham (2009) Prince of Networks. Bruno Latour and Metaphysics. re.press, Melbourne.

Latour, Bruno (1984) Les microbes: Guerre et paix suivi de Irréductions. Métailié, Paris.

Latour, Bruno (1987) Science in Action. How to follow scientists and engineers through society. Harvard University
Press, Cambridge, Massachusetts.

Latour, Bruno (1999) Pandora's Hope. Essays on the Reality of Science Studies. Harvard University Press, Cambridge, Massachusetts.

Latour, Bruno (2005) Reassembling the Social. An Introduction to Actor-Network-Theory. Oxford University Press, Oxford.

Latour, Bruno (2006 [1991]) Emme ole koskaan olleet moderneja. Suomentanut Risto Suikkanen. Vastapaino, Tampere.

Latour, Bruno (2010)"Coming out as a philosopher." Social Studies of Science 40:4, 599-608.

Latour, Bruno, Graham Harman \& Peter Erdélyi (2011) The Prince and the Wolf. Latour and Harman at the LSE. Zero Books, Winchester and Washington.

Lehtonen, Turo-Kimmo (2000) "Kuinka monta meitä on? Kollektiivin koettelua kolmessa Bruno Latourin tutkimuksessa”. tiede Eं edistys 25:4, 276-295. 